\title{
Liturgi Sakralisasi Barong-Rangda: Eksplorasi Teo-Filosofis Estetik Mistik Bali
}

\author{
Komang Indra Wirawan \\ Program Setudi Seni Drama Tari dan Musik, FPBS IKIP PGRI Bali \\ Jl. Seroja No.57, Tonja, Kec Denpasar Utara, Kota Denpasar, Bali 805235 \\ indrawirawan84@gmail.com
}

\begin{abstract}
Barong-Rangda selalu hadir dalam praktik-praktik beragama Hindu di Bali. Sosok yang dicitrakan sebagai Hyang Siwa dan Hyang Bhatari Uma selalu dihubungkan dengan dunia mistik, dan Rangda selalu dikaitkan dengan tokoh Calonarang bernama Datengdirah, yakni janda Girah dalam lotar Calonarang. Dalam kepercayaan masyarakat Hindu di Bali, Rangda adalah perwujudan dari Hyang Bhatari Durga sakti Bhatara Siwa dan sebagai penguasa kuburan yang dihubungkan dengan hal-hal yang menakutkan. Demikian pula Barong selalu dilekatkan dengan murthi Siwa dalam perwujudannya sebagai Banaspati Raja. Menariknya Barong-Rangda bukan saja dipahami sebagai simbol suci, tetapi dihayati dalam penghayatan yang beragam. Menariknya, sosok Barong-Rangda juga ditarikan oleh orang khusus yang disebut nyolahang Barong-Rangda atau menarikan sosok Barong-Rangda dalam ruang ritual dan pentas kesenian sakral. Berdasarkan hal tersebut, menarik untuk mengkaji liturgi sakralisasi Barong-Rangda, sehingga menemukan beberapa makna di dalamnya.
\end{abstract}

Kata kunci : sakralisasi, barong-rangda, teo-filosofis mistik bali

\section{Barong-Rangda Sacralization Liturgy: Bali Mystical Estetic Philosophical Exploration}

Barong-Rangda is always present in Hindu practices in Bali. The figures imaged as Hyang Siwa and Hyang Bhatari Uma are always associated with the mystical world, and Rangda is always associated with a Calonarang figure named Datengdirah, the widow of Girah in the Calonarang lotar. In the belief of the Hindu community in Bali, Rangda is the embodiment of the Hyang Bhatari Durga Sakti Bhatara Siwa and as the ruler of the grave that is associated with scary things. Likewise, Barong is always attached to the Shiva murthi in its manifestation as the King Banaspati. Interestingly Barong-Rangda is not only understood as a sacred symbol, but is lived in a variety of appreciation. Interestingly, the figure of the Barong-Rangda is also danced by a special person called the nyonganang Barong-Rangda or dances the figure of the Barong-Rangda in the ritual space and sacred arts stage. Based on this, it is interesting to study the liturgy of the Barong-Rangda sacralization, so as to find some meaning in it.

Keywords: sacralization, barong-rangda, mystical theo-philosophical bali

Proses Review : 1 - 20 Agustus 2019, Dinyatakan Lolos: 22 Agustus 2019 


\section{PENDAHULUAN}

Terdapat beragam rupa aktivitas budaya yang menyatu dengan berbagai sendi kehidupan dalam lingkungan sosial masyarakat Hindu di Bali. Aktivitas budaya tersebut merupakan ekspresi jiwa sebagai bentuk responnya terhadap alam lingkungan tempat hidupnya maupun sebagai bentuk respon terhadap pengalaman hidupnya. Oleh sebab itu, di setiap daerah memiliki kekhasan budaya sesuai dengan potensi alam maupun potensi SDM (baca: Sumber Daya Manusia) masing-masing daerah bersangkutan. Dari berbagai rupa aktivitas budaya masyarakat Hindu di Bali tersebut, salah satu di antaranya adalah aktivitas berkesenian (sakral-nonsakral) yang terdiri dari seni tari, seni rupa, seni lukis, seni suara, seni musik, seni sastra, dan sebagainya. Dan, diantara banyak ragam kesenian yang ditemukan di Kota Denpasar terdapat kesenian Barong-Rangda, baik sakral dan non sakral yang keberadaannya tersebar di beberapa desa di Kota Denpasar.

Kesenian Barong-Rangda tersebar di seluruh desa pakraman di Bali, tetapi tidak semua desa pakraman ataupun pura memiliki kesenian Barong-Rangda. Hal ini disebabkan terdapat berbagai alasan mengapa suatu pura masyarakatnya nyungsung tapakan Barong-Rangda, sementara di pura yang lain tidak ditemukan tapakan ini. Setiap tapakan Barong-Rangda di sebuah pura selanjutnya pada kesempatan-kesempatan tertentu dipentaskan sebagai kesenian sakral. Itu juga alasannya mengapa Barong-Rangda disebutkan sebagai aktivitas berkesenian (budaya), meskipun pada nantinya Barong-Rangda tidak semata-mata sebagai sebuah wujud kesenian, tetapi lebih jauh lagi ia merupakan implementasi teologi (ajaran ketuhanan) dari agama Hindu, baik menyangkut sisi filosofis (hakikat) keagamaan maupun psikologi (aspek kejiwaan/emosi) keagamaan. Tentang hal itu akan dibahas pembahasan selanjutnya.

\section{METODE PENELITIAN}

Metode penelitian dalam tulisan ilmiah ini menggunakan metode kualitatif dengan pendekatan deskripsi teologis dan filsafat seni. Connolly (2002:312) menjelaskan bahwasanya pendekatan teologi memfokuskan pada sejumlah konsep, khususnya didasarkan pada ide theos-logos, studi atau pengetahuan tentang Tuhan. Adapun Bandem (1996:62) menjelaskan bahwa pendekatan teo-estetika Hindu (baca: seni sakral; seni wali, dan seni bebali) seni pementasan di Bali yang sangat dekat dengan kajian keindahan merupakan media menurunkan kekuatan yang gaib dalam wujud seni, dan semua itu ada nilai filsafatinya. Sumber data dalam penelitian ini menggunakan sumber primer dan skunder. Selanjutnya teknik pengumpulan data dalam penelitian ini menggunakan beberapa teknik: (1) observasi partisipan, yakni peneliti terlibat dalam penelitian dan kajian; (2) wawancara yang digunakan adalah wawancara tidak terstruktur atau wawancara mendalam;
(3) pengumpulan data melalui studi dokumen, yaitu mengumpulkan data yang terkait dengan penelitian, baik dari buku, dan sumber lainnya yang sejenis. Teknik analisis datanya digunakan analisis deskriptif.

\section{ANALISIS DAN INTERPRETASI DATA}

\section{Pengertian Barong dan Rangda}

Ada banyak diskripsi yang menjelaskan tentang Barong. Namun demikian dalam kajian ini Barong yang dimaksudkan adalah "Suatu bentuk perwujudan atau sosok Banaspati Raja, yaitu wujud binatang gaib dengan kekuatan magis sebagai penjelmaan Dewa Siwa saat menghancurkan berbagai penyakit dan marabahaya." Dengan demikian, pengertian Barong disini adalah lebih kepada pengertian filosofis (tattwa Hindu) yang ada dalam teks-teks lontar yang menjelaskan tentang Barong dan Rangda. Demikian pula, Barong bukan lagi dipahami sebagai "binatang beruang" tetapi binatang gaib yang diwujudkan oleh tetua kita seperti apa yang kita lihat sekarang. Binatang gaib, tentunya memiliki kelebihan-kelebihan yang digambarkan dalam bentuk menyeramkan dan dipercaya memiliki kekuatan-kekuatan yang luar biasa (magis) sehingga masyarakat Bali meyakini sosoknya sebagai yang sakral (tenget).

Sedangkan Rangda disebutkan dalam uraian Gautama dan Sariani (2009:527), yakni: (1) janda; (2) peran dalam cerita Calonarang sebagai janda tukang sihir dari Girah dengan mengenakan topeng yang menyeramkan, mata besar melotot, taring besar-besar, rambut putih terurai lidah panjang, serta kuku panjang. Sementara itu Mardiwarsito (1986:463) dalam kamus Jawa Kuno menyebutkan "ran$d a$ ” berarti janda. Hal ini dipertegas oleh Segara (2000:20) yang menyebutkan istilah Rangda adalah bahasa Bali alus untuk penyebutan janda dari kalangan Tri Wangsa di Bali (Brahmana, Ksatrya, Wesya), sedangkan janda dari kalangan Sudra Wangsa dikenal dengan sebutan balu/walu.

Pada kalangan masyarakat umum di Bali istilah Rangda lebih dekat pada pengertian sosok tokoh berperingai jahat yang mempraktikkan ilmu hitam untuk menghancurkan masyarakat. Persepsi ini muncul karena masyarakat lebih akrab dengan pementasan seni drama Calonarang yang menempatkan Rangda sebagai tokoh antagonis di dalamnya. Rangda dalam cerita Calonarang ini adalah figur janda dari Raja Girah, sebuah wilayah kecil di Kerajaan Kediri, Jawa. Namun melihat kenyataan bahwa Rangda di Bali tidak semata-mata berfungsi sebagai peranti berkesenian, tetapi lebih penting fungsinya sebagai peranti keagamaan (arcanam/tapakan), maka perlu ditemukan pengertian yang lebih tepat menyangkut keberadaan Rangda tersebut. Untuk keperluan tersebut, selain mengacu pada Lontar Siwa Tattwa di atas, terdapat juga penyebutan Barong dan Rangda dalam Lontar Usadha Taru Pramana sebagaimana disebutkan bahwa ketika Sang Hyang Siwa mengalami sakit keras atau gering yang parah, untuk itu Sang Hyang 
Siwa menyuruh Dewi Uma mencari obat ke madyapada. Dalam pencarian obat untuk Dewa Siwa, Dewi Uma bertanya pada setiap pohon dan rumput-rumputan (sarwa taru dan sarwa lata). Kesemua pohon dan rumput itu dapat menjawab dengan baik, karena masing-masing sudah ada penghuninya, selanjutnya menerangkan khasiatnya masing-masing mulai dari akar, kulit, sampai dengan daunnya. Tepatlah pada tengah hari (kali tepet) sampailah Bhatari Uma di Setra Gandamayu, pada sebuah pohon besar, yaitu: Taru Rangdu, di sana beliau mengadakan tanya jawab tentang manfaat khasiat pohon tersebut. Kebetulan pada waktu itu merupakan hari yang terlarang oleh Sang Kala Banaspati Raja, karena pada saat itu yang menghuni pohon tersebut sedang tidur nyenyak.

\section{Jenis-Jenis Barong dan Rangda}

Keberadaan Barong dan Rangda tidak memiliki bentuk fisik yang baku, tetapi disesuaikan dengan ekspresi keindahan yang muncul dari tiap jiwa-jiwa pemuja yang berkehendak mempersembahkan karyanya semata-mata atas alasan bhakti. Itu pula alasannya mengapa di Bali dikenal beberapa bentuk Barong dan Rangda. Adapun bentuk-bentuk Barong yang ada dari berbagai sumber sebagai berikut.

1. Barong Ket sering juga disebut dengan Barong Ketket, Barong rentet, Barong Ketet. Jenis Barong ini merupakan penggambaran Banaspati Raja, yang berarti pelindung hutan atau pohon-pohonan. Bentuknya merupakan kombinasi dari singa, macan, sapi atau beruang yang memiliki kekuatan magis. Jenis Barong ini menyebar merata di seluruh Bali dan biasanya selalu berpasangan dengan Rangda. Di India terdapat binatang suci yang mirip Barong Ket yang bernama Sarabha. Sarabha artinya pembunuh, binatang mitos yang memiliki mata yang lebar (melotot) dan 8 kaki, yaitu 4 buah kaki normal dan 4 kaki lainnya melengkung ke atas yang menyerang dan membunuh singa-singa.Sarabha adalah penjelmaan Dewa Siwa untuk membunuh Narasimha, yaitu penjelmaan Wisnu untuk menghabisi raksasa Hiranyakashipu. Ceritanya adalah, setelah mengalahkan Hiranyakashipu, Narasimha tetap mengembara di bumi dengan galaknya menghancurkan segala sesuatu. Menyaksikan keadaan ini para dewa memohon bantuan Siwa. Siwa kemudian turun ke dunia menjadi Sarabha dan memotong tubuh Narasimha sehingga Dewa Wisnu dapat terbebas dari ikatan reinkarnasinya dan kembali ke Vaikunthaloka.

2. Barong Bangkal adalah babi yang umurnya sudah tua dengan tubuh besar dan taring panjang. Bangkal dianggap sebagai binatang mitos yang dihubungkan dengan kelahiran Bhoma. Figur ini dihubungkan dengan kisah pertarungan Wisnu dan Brahma untuk mencari ujung bawah dan atas Lingga Siwa. Wisnu mencari pangkal lingga turun ke dasar bumi menjadi babi, sementara Brahma melesat ke atas mencari puncak lingga menjadi burung layang-layang. Dalam pencariannya ke dasar bumi itulah Wisnu bertemu dengan Dewi Wasundari dan lahirlah Bhoma sebagai lambang kesuburan.

3. Barong Macan, yakni Barong dengan wajah atau topengnya berwujud kepala harimau. Barong ini dikaitkan dengan cerita Tantri. Terdapat hanya di beberapa desa saja di Bali dan sering dipentaskan saat ngelawang hari raya Galungan-Kuningan.

4. Barong Asu, yakni berasal dari asu, yakni kata alus bahasa Bali yang berarti anjing. Wajah topeng Barong ini memang menyerupai kepala anjing dan juga disakralkan. Pementasannya pun dilaksanakan dengan ngelawang saat Galungan-Kuningan.

5. Barong Gajah, yakni Barong dengan kepala menyerupai gajah. Dipertunjukkan saat rangkaian hari raya Galungan-Kuningan.

6. Barong Sampi. Barong ini juga langka hanya terdapat di desa tertentu saja. Digunakan ngelawang saat Galungan-Kuningan.

7. Barong Singa. Hanya terdapat di Kabupaten Buleleng berfungsi sebagai penolak bala.

8. Barong Landung. Barong ini tidak berwujud binatang, tetapi berwujud manusia laki-laki dan perempuan. Kata landung dalam bahasa Bali berarti tinggi, karena memang wujud barong ini, baik yang laki-laki maupun yang perempuan fostur tubuhnya tinggi.Dimainkan seperti ondel-ondel Betawi dan dipentaskan saat-saat tertentu sebagai penolak bala, baik saat hari raya Galungan-Kuningan maupun hari lain yang dianggap perlu.

9. Barong Brutuk. Barong ini hanya terdapat di Desa Trunyan, Kabupaten Bangli. Topeng ini juga tidak menyerupai binatang dan dimainkan oleh satu orang saja. Barong ini memiliki topeng raksasa sebagai perwujudan Dewa Pancering Jagat. Barong Brutuk berpasangan laki-laki dan perempuan, tetapi semuanya dimainkan oleh laki-laki dengan bersenjatakan cemeti dan tanpa gamelan pengiring. Bulu-bulu Barong Brutuk terbuat dari kraras (daun pisang kering). Dipertunjukkan saat hari-hari tertentu saja dan puncak pertunjukan ditandai dengan bertemuanya Barong Brutuk laki-laki dan perempuan sebagai simbol terjadinya kesuburan.

10. Barong Blas-blasan atau disebut juga Barong Kedingkling dan Nongkling. Barong ini terdiri dari banyak wujud umumnya bertopeng para tokoh dalam pewayangan Ramayana. Biasanya dipentaskan dengan ngelawang dengan diiringi gamelan batel, bebarongan.

11. Barong Gegombrangan. Jenis Barong ini sudah sangat jarang dijumpai. Kata gombrang artinya rambut yang terurai. Mungkin Barong ini adalah Barong Memedi yang masih terdapat di beberapa desa di Bali.

12. Barong Sae. Diduga Barong ini kena pengaruh China dengan topeng berwajah macan atau kelelawar.

13. Barong Jaran, yaitu Barong dengan topeng 
menyerupai kepala kuda.

14. Barong Manjangan, yaitu Barong dengan topeng menyerupai kepala rusa atau menjangan.

15. Barong Dawang-Dawang. Merupakan variasi dari Barong Landung di daerah Tabanan, topengnya berwujud seram dan berukuran besar. Di Desa Muncan, Karangasem, Dawang-Dawang (untuk yang laki-laki) dan Dudong (untuk yang perempuan) digunakan sebagai pelengkap ngaben, yakni mengiringi wadah ke setra bersamaan dengan petulangan berupa sapi, singa, gajahmina. Sementara itu di Denpasar tidak terdapat Dawang-Dawang, tetapi yang ada adalah Ogoh-Ogoh yang dikaitkan dengan upacara Nyepi dengan wajah topeng menyerupai bhutakala.

Sementara itu untuk Rangda biasanya tidak saja dibedakan atas dasar bentuk wajah topengnya, melainkan dibedakan dari warna topeng. Sedikitnya terdapat dua jenis Rangda yang dibedakan atas warnanya, yaitu Ratu Ayu untuk topeng Rangda dengan cat putih, dan Ratu Mas dengan cat topeng berwarna merah. Tidak di setiap desa Rangda ratu Ayu dan Ratu Mas ini berpasangan, dimana adakalanya hanya terdapat Rangda Ratu Ayu saja yang berpasangan dengan Barong, demikian juga hanya terdapat Rangda Ratu Mas saja juga bersanding dengan Barong. Sedangkan dari segi bentuknya Rangda sulit dibedakan karena semuanya mirip, hanya saja pembedaan tersebut didasarkan atas gaya topeng oleh seniman pembuatnya atau style pemahatnya. Untuk kategori bentuk, topeng Rangda dibedakan: (a) Bentuk Nyinga, yaitu topeng dengan sedikit menonjol ke depan menyerupai singa. Ekspresi topeng style ini biasanya harus berkesan galak dan buas; (b) Bentuk Nyleme, yaitu apabila bentuk topeng Rangda ini dengan wajah menyerupai wajah manusia, melebar dan tidak terlalu menonjol. Ekspresi yang ditampilkan oleh topeng bentuk ini adalah ketenangan, angker berwibawa; (c) Bentuk Raksasa, bentuk ini yang penting menyeramkan sebagaimana bayangan orang tentang raksasa yang menakutkan, dan umumnya topeng Rangda bentuk ini yang banyak terdapat di masyarakat. Selanjutnya ada gaya atau pakem Rangda yang berbeda-beda di masing-masing daerah tergantung pada desa, kala, patra dan mewacara.

\section{Membuat Barong dan Rangda yang Mataksu}

Tahapan pembuatan tapel (topeng) Barong dan Rangda:

\section{1) Nyanjan}

Proses ini adalah tahap awal pembuatan Barong dan Rang$d a$ dengan didahului matur piuning (mempermaklumkan ke hadapan Ida Bhatara) di pura tempat dimana nantinya Barong dan Rangda tersebut disthanakan sebagai pratima. Nyanjan ini biasanya disertai dengan pertanda gaib berupa adanya pemangku yang kerasukan Ida Bhatara untuk memberi petunjuk mengenai direstui tidaknya pembuatan atau perbaikan (kalau sebelumnya sudah ada) Barong maupun Rangda. Hasil dari proses Nyanjan di setiap tempat tentu berbeda-beda, tetapi ada kalanya petunjuk Ida Bhatara lewat Nyanjan itu sangat terinci, seperti menunjukkan

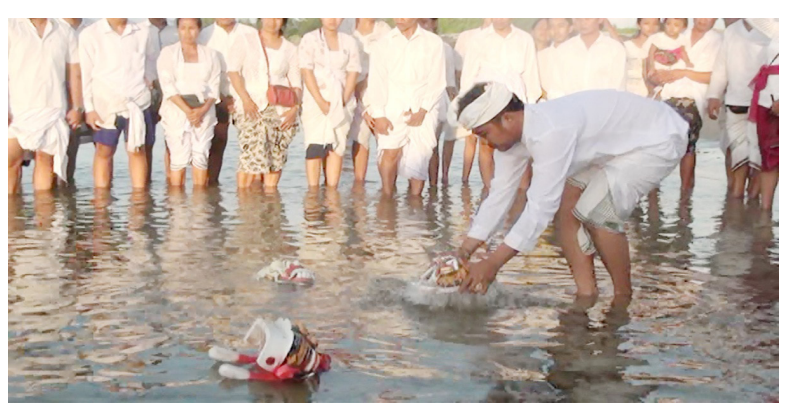

Gambar 1. Prosesi Ngayut Dalam Prosesi Pembuatan Barong dan Rangda (Sumber: Gases Bali,2018)

dimana harus dicari bahan tapel Barong dan Rangda yang akan dibuat. Kalau petunjuk gaib tersebut menyebutkan bahwa bahan kayu tapel harus dicari di arah kaja kangin dari tempat pura, maka masyarakat harus menemukan pohon pule, kepuh, kepah (sesuai petunjuk) ke arah tersebut sampai kayu dimaksud ditemukan, apabila kayu dimaksudkan sudah ketemu, maka dilanjutkan dengan mohon izin kepada pemilik kayu serta permohonan secara gaib. Dari proses ini sering muncul ikatan gaib antara Barong dan Rangda yang baru dibuat dengan tempat dimana kayu tersebut diperoleh. Ikatan ini terutama terjadi apabila kayu bahan tapel tersebut diperoleh di wewidangan (areal) pura tententu atau setra sebuah desa adat. Ikatan gaib dari Barong dan Rangda dengan tempat bahan tapel itu diperoleh biasanya ditandai dengan dihadirkannya Barong dan Rangda tersebut pada setiap pujawali (upacara agama Hindu) di pura tempat bahan tapel itu didapat. Ikatan simbolik ini tentu membawa ikatan sosial juga antara masyarakat penyungsung Barong dan Rangda yang baru dibuat itu dengan masyarakat tempat dimana bahan tapel tersebut diperoleh.

\section{2) Ngepel Kayu}

Ngepel Kayu adalah proses pemotongan kayu bahan tapel di pohon yang masih berdiri kokoh, mengingat bahan tapel Barong dan Rangda tidak boleh berasal dari pohon yang sudah tumbang ataupun sudah mati walaupun masih berdiri. Diperlukan teknik khusus untuk memotong bahan tapel agar pohon induk tidak ikut roboh saar diambil sebagian kayunya. Ngepel kayu pun memilih hari dewasa ayu, biasanya dilakukan pada saat Tilem dengan terlebih dahulu memohon izin kepada dewaning taru bersarana banten $\mathrm{Pa}$ jati yang berisikan Pras, Ajuman soda, dan Daksina lengkap dengan pesucian dan segehan cacah.

Sebuah metode bisa ditempuh apabila berkehendak Barong dan Rangda yang akan dibuat tidak terikat secara sosial-ritual dengan tempat dimana bahan kayunya diambil. Apabila kedua pihak sepakat, yaitu antara pemohon kayu bahan tapel dan pemilik kayu pule, kepuh, kepah, dll bahwa Barong dan Rangda yang akan dibuat dari bahan tersebut nantinya tidak harus dihadirkan (katangkilang) pada setiap piodalan di pura tempat kayu itu dimohon (pemilik kayu), maka untuk memutuskan ikatan niskala dari unsur kegaiban dapat dilakukan dengan cara membawa poton- 
gan kayu seteleh dipotong dari batangnya ke segara (laut). Dengan mengikatkan tali pada potongan kayu tersebut, bahan tersebut dilemparkan ke laut sebagai simbolik dihanyutkan, tetapi talinya tetap dipegang sehingga potongan bahan tapel itu tidak hanyut sungguhan. Menurut kepercayaan Hindu segara adalah di bawah kekuasaan Hyang Baruna sehingga segala sesuatu yang sudah berada di lautan menjadi kekuasaannya. Setelah potongan kayu mengapung di air selanjutnya dilakukan upacara permohonan ke hadapan Bhatara Baruna, agar berkenan menganugerahkan kayu segara itu untuk dijadikan pelawatan Barong dan Rangda oleh masyarakat. Setelah prosesi itu bahan tapel tersebut dibawa pulang dan secara niskala sudah memutus hubungan dengan tempat dimana potongan kayu itu didapat sehingga kelak di kemudian hari tidak ada keharusan nangkilang tapakan tersebut ke tempat bahan pembuatnya dulu dicari, tetapi cukup turut dihadirkan apabila dikehendaki secara sukarela.

\section{3) Membuat Barong dan Rangda}

Saat Ngepel kayu tersebut krama desa atau penyungsung pura yang akan menggunakan Barong dan Rangda tersebut turut datang mendak (menjemput) bahan tersebut disertai gamelan baleganjur (meski tidak harus demikian) kemudian potongan kayu kapundut (digotong) pulang dengan berjalan kaki. Bahan tapel terlebih dahulu kalinggihang (ditempatkan terlebih dahulu di pura tempat dimana Barong-Rangda tersebut akan dijadikan sungsungan untuk diberi wastra (pakaian) dan upacara matur piuning sebagaimana mestinya. Kemudian apabila sudah tiba waktu mulai pengukiran tapel tersebut, bahan kayu dibawa ke rumah undagi. Pahatan pertama adakalanya dilakukan oleh sulinggih sebelum digarap oleh undagi.

Waktu (kala) merupakan hal yang sangat penting dalam pembuatan sebuah pratima yang nantinya diharapkan dapat mataksu. Pembuatan benda-benda sakral harus dibuat dengan proses sakral pula, di antaranya pemilihan waktu yang dianggap keramat, pembuatnya dalam keadaan suci (tidak cuntaka), dibuat di tempat yang sudah disakralisasi, dan seterusnya. Saat yang ideal untuk Ngepel atau memotong kayu bahan tapel Barong dan Rangda ialah ketika jatuh pada sasih Kasa dan Karo, dan Sada. Pada ketiga sasih ini kayu berada dalam kondisi yang baik tingkat kekeringannya sehingga memudahkan untuk diukir. Pada sasih ini pohon-pohonan tidak sedang menyerap makanan (air) sehingga pori-pori kayu cenderung tertutup. Keadaan ini menciptakan kayu menjadi tahan lama dan tidak mudah lapuk. Sementara itu hari yang baik untuk memulai pembuatannya (mengukir tapel) adalah pada Kajeng Kliwon karena hari itu dianggap sakral (keramat) dimana Dewa Siwa disebutkan tengah beryoga pada hari tersebut. Oleh karena itu saat Kajeng Kliwon akan memiliki kekuatan atau daya sakti yang ampuh untuk membuat Barong ataupun Rangda. Sebagaimana yang berlaku dalam tradisi Hindu di Bali, hari Pasah hendaknya dihindari untuk kegiatan-kegiatan penting termasuk pembuatan tapel untuk

\section{tapakan.}

Barong dan Rangda yang bisa disebut Barong dan Rangda adalah yang bentuk fisiknya sudah selesai dan rampung melewati proses sakralisasi lewat upacara Ngereh di setra. Jadi, sebelum melalui proses upacara tersebut meskipun benda tersebut sudah berwujud Barong dan Rangda, maka status benda itu hanya sebagai "Barong Barongan" dan "Rangda-Rangdaan” atau imitasi Barong dan Rangda dan tidak dapat difungsikan sebagai tapakan Ida Bhatara. Khusus untuk proses pembuatan fisik Barong dan Rangda dapat diuraikan sebagaimana di bawah ini:

\section{a) Pengumpulan Bahan}

Semua jenis bahan yang diperlukan meliputi kayu, rambut, kain, hiasan, maupun sarana pendukung lain dikumpulkan dalam suatu tempat tertentu agar mudah penggarapannya dan menyesuaikan (harmonisasi) ukuran dari tiap bagian Barong dan Rangda.

\section{b) Pengolahan Kayu}

Kayu bahan tapel hendaknya diolah terlebih dahulu sebelum digarap. Kayu bahan sebaiknya direbus dahulu (punpun) dalam air mendidih. Beberapa kalangan menjadikan proses ini sebagai deteksi bahan Rangda, yaitu apabila air hasil rebusan yang satu lebih bening dengan yang lain, maka yang air rebusannya lebih bening dijadikan bahan Rangda Ratu Ayu (cat putih), dan yang air rebusannya warna kemerahan dijadikan bahan Rangda Ratu Mas atau bahan tapel Barong. Setelah perebusan cukup, maka kayu diangin-anginkan dan dilanjutkan dengan pengeringan hingga bahan siap diukir. Tingkat kekeringan kayu pun harus pas untuk menghindari terjadinya pengerutan setelah tapel diukir akibat kadar airnya masih tinggi.

c) Makalin (Membuat Bakal Tapel)

kayu yang sudah siap digarap mulai dibentuk dengan menggarap bakal atau sket globalnya. Biasanya dilakukan dengan membuat guratan atau sisiran-sisiran kasar yang mengarah pada bentuk dasar dari wajah Barong dan Rangda. Proses ini disebut makalin atau membentuk wujud kasar, kalau dalam bangunan fase ini adalah proses membuat fondasi. Tahap ini merupakan merekayasa desain awal sehingga setelah terbentuk bakal maka undagi (tukang pahat) sudah bisa memperkirakan dimana tempat-tempat untuk memahat mata, hidung, pipi maupun yang lain. Hal ini dilakukan agar terdapat keserasian posisi atau anatomi wajah tapel agar memudahkan pemahatan berikutnya.

\section{d) Memahat (ngukir tapel)}

Setelah pembuatan bakal atau bentuk dasar rampung, maka dilanjutkan untuk pemahatan sesuai desain dasar yang ada. Setiap undagi Barong dan Rangda memiliki pengetahuan tentang alat-alat pahatnya. Setiap alat memiliki fungsi masing-masing sehingga pemahat tinggal memakai sesuai corak pahatan yang akan dibuat.

Seorang undagi Barong dan Rangda adalah seorang 
pamangku, yaitu pemangku undagi yang berarti yang bersangkutan sudah melalui proses pawintenan pamangku sebagai ritual penyucian diri. Sebagai seorang Pamangku Undagi, setiap melakukan proses pemahatan maupun proses pembuatan lainnya, maka undagi tersebut pun terlebih dahulu menyucikan dirinya. Hal ini bertujuan agar tapel Barong dan Rangda yang dihasilkan benar-benar memancarkan vibrasi kesucian yang kuat atau mecaya (bercahaya spiritual). Konsentrasi si pemahat tapel Barong dan Rangda untuk tapakan Ida Bhatara adalah tindakan tapa seorang seniman untuk menghasilkan produk yang bermutu sebagaimana halnya mpu keris melakukan konsentrasi dan mencurahkan batinnya pada karya yang dibuatnya. Hal ini bertujuan untuk menghasilkan karya yang mataksu.

\section{d) Proses Pengecatan}

Setelah tapel selesai diukir diakhiri dengan proses menghaluskan (ngamplas), maka tahap berikutnya adalah pengecatan. Pengecatan disesuaikan dengan kebutuhan dan warna pilihan. Diawali dengan penutupan pori-pori kayu dengan plamir dan sejenisnya. Berikutnya pemolesan cat dasar dan terakhir pemolesan cat dengan detail warna menurut bagian-bagian yang dicat. Pada saat pengecatan Barong-Rangda ada beberapa jenis warna yang digunakan, dan Barong maupun Rangda yang berkualitas baik adalah menggunakan warna alami. Misalnya warna putih dibuat dari tulang, merah dengan kayu tiga gancu, warna hitam dengan areng pohon pinus dan warna alami lainnya. Belakangan ini sangat jarang menggunakan warna alami karena prosesnya sangat lama, tetapi kualitas warna tetap dijaga agar tahan lama dan alami sehingga Barong-Rangda Nampak hidup dan matkasu.

\section{e) Pembuatan Perlengkapan Lain}

Selain proses penggarapan tapel, saat bersamaan juga disiapkan perlengkapan lain, seperti membuat kerangka Barong dan Rangda. Kerangka dibuat dengan bahan baku bambu tali (Tiing tali) yang sudah dihaluskan dan dibelah sesuai dengan kebutuhan. Keranjang Barong terdiri dari keranjang pundut, yaitu dua buah keranjang yang dianyam dengan rotan dan bambu tali. Lebar keranjang kira-kira satu meter persegi ditempatkan di bagian depan dan yang lain di bagian belakang. Bagian depan berbentuk setengah lingkaran, dan bagian belakang setengah lingkaran lengkap dengan rotan besar sebagai pangkal ekor Barong. Perlengkapan lainnya adalah tangga tali, sunan yang dipasang di bagian tengah atas keranjang, di depan dan belakang, keduanya dipasangi sunan sebagai penyangga Barong dan Rangda jika ditarikan sebagai tempat kepala pemundut. Selanjutnya bulu Barong dipasang dengan mempergunakan tali dan praksok serta rambut Kuda yang sudah diikat dengan mempergunakan tangga tali. Kemudian, di bagian depan dipasang bulu dengan warna hitam yang terbuat dari ijuk. Kemudian di bagian ekor dipasangkan bulu Burung Merak sebanyak sembilan helai bulu ekor. Pada bagian ekor Barong juga dipasang genta kecil sebagai lonceng. Cangkokan kaca, ini ditempel di ukiran

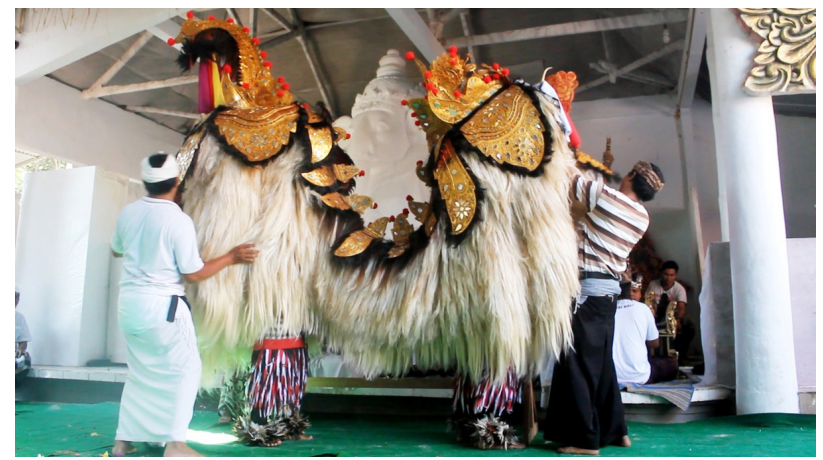

Gambar 2. Finising Pembuatan Barong di Gases Bali (Sumber: Gases Bali,2018)

Mal yang sudah selesai di-prada dengan mempergunakan prada gede. Kemudian pemasangan wastra, Angkep pala, ditempatkan di bagian depan keranjang belakang dan di bagian belakang keranjang depan. Kemudian, gelungan di atas keranjang depan. Garuda mungkur di belakang atas keranjang depan. Berikutnya, ekor di bagian belakang atas. Ampok-ampok di bagian samping keranjang depan dan belakang. Badong di bagian depan keranjang depan.

\section{f) Finishing}

Pengerjaan akhir adalah finishing, yaitu memeriksa secara keseluruhan hasil rakitan Barong maupun Rangda. Dalam finishing ini bisa dilakukan suatu tes percobaan atau dipakai seperti saat akan dimainkan. Setelah diperagakan akan terasa enak atau tidaknya atau ada hal-hal lain yang perlu dibenahi. Jika semua sudah dianggap baik maka Barong maupun Rangda sudah siap digunakan dan untuk selanjutnya dilakukan prosesi penyucian (sakralisasi).

Dengan selesainya pembentukan fisik Barong dan Rangda berarti sudah siap disakralisasi untuk menyucikan tapak tersebut dan memohonkan kekuatan gaib agar berkenan bersthana pada tapakan. Prosesi sakralisasi Barong dan Rangda berlangsung beberapa tahapan dan cukup rumit sehingga hanya sedikit orang yang memiliki kemahiran di bidang ini. Hal ini mengingat setelah Barong dan Rangda itu berada dalam keadaan suci (sakral), maka hal itu pun belum cukup memenuhi syarat untuk dijadikan pratima atau pralingga Ida Bhatara. Ada tahap terakhir yang harus di tempuh, yaitu pengisian jiwa atau roh dewata yang dimohonkan hadir dan berstahanya padanya. Tahapan pengisian atau penghidupan Barong dan Rangda agar dijiwai oleh kekuatan suci kedewataan ini disebut upacara Ngereh, pelaksanaannya disebut Ngerehang Barong dan Rangda. Hanya Barong dan Rangda yang sudah melewati prosesi penyucian dapat dilakukan upacara Ngereh.

\section{Sakralisasi Barong dan Rangda}

Barong maupun Rangda yang sudah selesai dibuat merupakan barang seni yang dalam konteks religiusitas masih tergolong benda profan (non sakral), sehingga tidak memiliki makna atau simbolik apapun selain sebuah citra seni. Oleh karena Barong maupun Rangda tersebut akan digu- 
nakan sebagai simbol keagamaan maka perlu diadakan proses transit atau pemindahan predikat dan kualitas dari wujud profan menuju sakral. Sebagai manusia religius alam tidak pernah hanya sesuatu yang alami; alam selalu penuh dengan yang religius. Hal ini mudah untuk dipahami karena kosmos merupakan ciptaan ilahi; berasal dari kekuasaan dewa-dewa, dunia dipenuhi oleh kesakralan.

Sakralisasi benda simbol keagamaan Hindu di Bali, dalam hal ini Barong dan Rangda dilakukan melalui upacara yadnya. Secara etimologi kata yadnya merupakan bahasa Sanskerta, yaitu berasal dari urat kata yaj yang berarti pengorbanan dengan penuh cinta kasih. Bersumber dari akar kata tersebut kemudian berkembang menjadi beberapa istilah, antara lain yajna, yajus, dan yajamana. Kata yadnya itu sendiri berarti pemujaan, persembahan atau korban suci. Kata yajus artinya aturan-aturan tentang yadnya, sedangkan yajamana merupakan salah satu unsur dari yang disebut tri manggalaning yadnya, yaitu tiga unsur penting dalam pelaksanaan yadnya yang terdiri dari tiga unsur, yaitu (1) orang yang memimpin upacara tersebut (pemuput); (2) orang yang membuat sesajen (tapini yajna); dan (3) orang yang melaksanakan yajna atau sang yajamana. Selaian itu, yang memimpin upacara sakralisasi juga dapat dilakukan oleh orang yang sudah mawinten seperti pemangku undagi, pemangku desa, dan sejenisnya. Terlebih pemangku yang sudah ngiringang Dalem sudah pasti memiliki kualifikasi dalam hal tersebut. Sebab dalam konteks sakralisasi atau ngerehang dan mesuci peran pemimpin upacara sangat penting. Oleh karena itu, orang-orang yang sudah memiliki taksu dalem sangat berhak melakukan prosesi tersebut, sebab bise, dadi dan patut sangat perlu diperhatikan dengan baik. Adapun upacara yadnya dalam proses sakralisasi Barong dan Rangda ini terdiri dari berbagai tahapan antara lain:

\section{a) Melasti ke Segara}

Pertama-tama Barong dan Rangda dibawa ke segara untuk melakukan penyucian atau disebut melasti. Ritual melasti bermakna menghanyutkan leteh di bhuana alit dan bhuana agung dan kemudian memohon saripati amrtha di telenging segara. Dalam kaitannya dengan sakralisasi Barong dan Rangda, upacara melasti ke segara bermaksud menghanyutkan "kekotoran" yang terdapat pada Barong dan Rangda yang berasal dari proses pembuatan yang tentu saja menyebabkan banyak kecemaran secara spiritual, demikian juga bahan-bahan Barong dan Rangda beserta perlengkapannya yang berasal dari berbagai tempat yang mungkin saja mengandung berbagai "kekotoran", maka dimohonkan kepada Hyang Baruna sebagai penguasa lautan untuk meleburnya. Selain itu melasti dalam rangkaian upacara sakralisasi ini bertujuan menghanyutkan kekotoran batin krama desa yang akan melangsungkan upacara penyucian Barong dan Rangda sehingga proses sakralisasi dapat berjalan lancar dan diliputi aura kesucian. Kekotoran batin tersebut berupa Tri Mala dan Tri Mala Paksa. Tri Mala terdiri dari: (1) Mithia Hrdaya, yaitu selalu ber- perasaan dan berpikiran buruk, berburuk sangka kepada orang lain, (2) Mithia Wacana, yaitu berkata sombong, angkuh, tidak menepati janji, (3) Mithia laksana, yaitu berbuat tidak sopan, kurang ajar, hingga merugikan orang lain. Sedangkan Tri Mala Paksa terdiri dari: (1) Kasmala, yaitu perbuatan yang hina dan kotor, (2) Mada, yaitu perkataan, pembicaraan yang dusta dan kotor, (3) Moha, yaitu pikiran dan perasaan yang curang dan angkuh.

Melasti ke segara ini yang didukung oleh berbagai sarana banten yang diperlukan sebagai sarana simbolis untuk memohon tirtha dari segara untuk dipercikkan pada Barong dan Rangda serta umat pengiring. Selanjutnya perlu juga dijelaskan, bahwa melasti dapat dilakukan pula sebelum pensakralisasian dan sesudah prosesi pensakralisasian. Sebelum proses pemasupatian melakukan melasti adalah tujuannya sama, yakni penyucian karena Barong dan Rangda pasti dibuat oleh Undagi sehingga perlu disucikan terlebih dahulu dari segala kekotoran setelah dikerjakan. Tujuan melasti setelah pamasupatian memiliki makna yang sama juga, bahwa setelah terlahir maka perlu Ida Bhatara disucikan kembali.

\section{b) Melaspas}

Tahapan proses sakralisasi berikutnya adalah melaspas Barong dan Rangda. Mlaspas berasal dari kata "paspas". Mendapat infik "el" menjadi pelaspas, merupakan kata kerja aktif yang artinya pembersihan atau penyucian. Lalu disengaukan menjadi "melaspas" atau mlaspas, melakukan pekerjaan (aktif) untuk membersihkan atau menyucikan. Jadi Melaspas artinya penyucian atau "sakralisasi sebuah bangunan yang akan difungsikan. Mlaspas maksudnya melepaskan segala ikatan dari bahan-bahan Barong dan Rangda dengan asal-muasal bahan tersebut. Seperti melepaskan ikatan atau keterkaitan tapel denga asal kayu, bamboo, kain, benang, dan lainnya, sehingga ada penegasan sejak upacara melaspas tersebut kayu tapel tersebut bukan lagi sepotong kayu pule, tetapi sudah berubah status menjadi Barong dan Rangda. Demikian juga bahan-bahan lainnya tidak lagi berpredikat sebagai bamboo tiying tali, bulu jaran, dan sebagainya, tetapi sudah menjadi kesatuan utuh wujud Barong dan Rangda.

Adapun rangkaian Melaspas adalah (a) Mecaru Pancasata. Pada saat melaspas acara mecaru atau memberikan persembahan kepada bhutakala agar menjadi saumya (tenang dan lembut) dengan harapan segala sesuatu yang akan dilakukan selanjutnya dirasakan terbebas dari godaan-godaan dari kekuatan bhutakala. Mecaru ini upaya memuliakan semua tingkatan roh, bhutakala, dengen, durga, bregala-bregali, pisaca, dan lain-lain agar menjadi meningkat derajatnya menjadi sifat kedewataan dan memberikan vibrasi positif pada manusia. Mecaru Pancasata yaitu pengorbanan binatang berupa ayam yang terdiri dari lima ekor ayam dengan jenis warna mulai dari warna putih untuk nyomya bhuta di arah timur, ayam warna merah untuk nyomnya bhuta di arah selatan, ayam kuning untuk 
nyomya bhuta di arah barat, ayam hitam untuk nyomnya bhuta di arah utara, dan ayam brumbun sebagai pusat pengider-ider (poros mata angin) untuk nyomnya semua jenis bhuta di arah atas dan bawah; (b) Membersihkan dengan Sarana Banten. Setelah pecaruan, maka tahapan melaspas selanjutnya adalah melakukan penyucian Barong dan Rangda dengan sarana banten. Adapun berbagai banten yang dipakai pada ritual ini diantaranya adalah (1) Banten Bayakaonan. Banten ini merupakan sarana upacara pembersihan yang khusus untuk membersihkan bagian bawah pada Barong maupun Rangda. Hal ini dilakukan mengingat Barong Maupun Rangda sudah dianggap sebagai bentuk binatang yang hidup sebagai wahana atau alat yang akan dihidupkan maka Barong maupun Rangda sudah mewakili wujud yang sesungguhnya dan selanjutnya setelah dibersihkan bagian bawahnya yaitu telapak kakinya sudah siap untuk dibersihkan pada bagian tengah yaitu dengan sarana banten selanjutnya; (2) Banten Tatebasan Durmanggala. Banten ini digunakan untuk melanjutkan pembersihan tubuh Barong maupun Rangda pada bagian tengah ke bawah, yaitu di bawah leher dan selanjutnya menurun ke bawah sebagai simbol menghilangkan segala kadurmanggalaan atau segala kesalahan yang dibuat baik sengaja maupun tidak disengaja sehingga segalanya menjadi baik adanya dan selanjutnya diteruskan dengan sarana pembersiahan berikutnya; (3) Banten Tatebasan Prayascitta. Sarana banten ini digunakan khusus dalam fungsinya untuk menetralisir segala kedukaan atau kesedihan yang terjadi akibat proses pembuatan Barong maupun Rangda yang memakan waktu begitu lama. Selama proses pengerjaan tersebut tentu terdapat berbagai permasalahan yang dimunculkan dan dengan banten Prayascitta dimohonkan kekuatan dewata melenyapkan kedukaan tersebut dan berubah menjadi galang apadang (riang gembira). Banten ini dipakai untuk membersihkan seluruh tubuh Barong maupun Rangda dari kepala sampai kakinya; (4) Banten Pangulapan. Sarana banten Pangulapan ini ditujukan untuk menyempurnakan berbagai kekurangan pada Barong maupun Rangda baik pada saat dibuat maupun saat akhir pembuatan sehingga siap menerima roh atau tapakan yang akan menempatinya.; (5) Lis Balegading. Rangkain selanjutnya yaitu memberikan pembersihan dengan simbol Lis atau senjata dewa-dewa serta memberikan Bale atau rumah kencana/emas yang disimbolkan dengan bentuk rumah yang terbuat dari janur kuning dari daun kelapa gading. Jika banten ini sudah diberikan menandakan bahwa rangkaian pembersihan sudah lengkap dan dianggap Barong maupun Rangda sudah siap untuk menerima kehadiran roh dewata atau kekuatan sakti yang akan menempatinya.

\section{C) Memakuh}

Setelah rangkaian pembersihan dilakukan seperti dinatas, selanjutnya diadakan ritual pemakuhan. Memakuh artinya melakukan kegiatan "Makuh." Makuh berasal dari kata "bakuh" yang artinya kuat, atau kokoh. Mendapat anusuara M, membentuk kata kerja aktif, yakni menjadikan "kokoh" atau "kuat" secara spiritual. Dengan demikian upacara memakuh bermakna mengokohkan keberadaan Barong dan Rangda secara spiritual agar kehadirannya di tengah-tengah masyarakat penyungsung dapat ajeg atau kokoh, baik secara fisik maupun secara spiritual. Selain itu memakuh ini sebagai simbolisasi bahwa Barong maupun Rangda sudah selesai dibuat sebagai simbol tugas akhir dari undagi atau tukang yang sesungguhnya dilakukan oleh orang suci, namun karena orang suci (sulinggih) atau orang yang ditunjuk ketika nyanjaan tidak ahli memahat tapel, maka meminta bantuan orang lain. Pada memakuh dilakukan pertanggungjawaban secara niskala untuk bersaksi bahwa yang membuat Barong dan Rangda itu adalah orang suci. Sulinggih atau orang yang ditunjuk untuk memahat tapel itu saat nyanjaan sesuai petunjuk gaib, tetapi oleh karena keterbatasannya tidak mampu membuat tapel dan mewakilkan kepada ahlinya, maka saat upacara memakuh orang yang ditunjuk secara niskala tersebut memegang alat pertukangan sebagai simbol melakukan pengerjaan akhir Barong dan Rangda sebagai tanda yang bersangkutan adalah pihak yang bertanggung jawab dalam proses pembuatan Barong dan Rangda itu.

\section{d) Mapengurip-urip}

Kegiatan selanjutnya yang dilakukan setelah memakuh adalah mepengurip-urip atau memberi simbol kehidupan pada Barong dan Rangda. Sarana dalam acara ini ada berbagai macam seperti warna merah darah, warna kuning dari kunyit, warna putih dari kapur dan warna hitam. Masing-masing warna dioleskan pada bagian dari Barong maupun Rangda sebagai simbolisasi kelengkapan atas unsur warna yang seharusnya dimiliki oleh benda yang akan dihidupkan dengan sarana banten selayaknya badan manusia yang juga memiliki unsur warna macam lima. Dengan ritual ini sudah dianggap melengkapi segala unsur yang diperlukan untuk terbentuknya suatu badan atau tubuh atau Linggih Bhatara berupa Barong maupun Linggih Bhatari berupa Rangda yang selanjutnya siap ditempati suatu unsur niskala yaitu kekuatan dewata.

\section{e) Mepasupati}

Pasupati adalah nama lain dari Sang Hyang Siwa. Menurut kamus Sanskerta (Surada, 2007: 206) pasupati artinya seorang pengembala; gembala; Dewa Siwa. Dengan demikian, upacara mepasupati maksudnya adalah sebuah ritual untuk memohon kepada Tuhan yang dalam manifestasinya sebagai Sang Hyang Siwa untuk berkenan menjadi pengendali atau memberikan kekuatan terhadap Barong dan Rangda. Pada Lontar Pemlaspas Pamasupatian Barong-Rangda (koleksi Pusat Dokumentasi Porvinsi Bali, 1998) diuraikan tentang proses penyucian yang dilakukan oleh pandita. Disebutkan sebelum muput upacara, pandita berkumur dan membersihkan kaki yang mempergunakan mantra. Kalau dihitung maka akan ada sebelas tahapan hingga sampai pada tahapan Dipa Kangga. Setelah itu, akan dilanjutkan dengan: (1) Nyiratang Tirtha Siwatamba, mantra Siwa Surya dengan dua kalpika yang diletakkan di sebelah Siwamba. Kemudian dilanjutkan dengan nuntun 
Barong dan Rangda dengan jalan mengambil bunga tunjung dan mengucapkan mantra yang terkait dengan upacara pasupati. (2) Membuat Taksu Barong dan Rangda. (3) Nyiratang toya siwamba pada Rangda lingga bunga, dan dilemparkan jatuh pada Rangda, dan dilanjutkan dengan air cendana dan beras. (4) Menyembah dengan sarana bunga dari bawah ke atas, ngayabang dupa dan menaburkan bunga kembali. Pada upacara tersebut digunakan kalpika sebanyak dua buah simbolik dari Sang Hyang Siwa dan Sang Hyang Surya yang memberikan jiwa dan saksi pada upacara tersebut. Kalpika merupakan sebuah perwujudan lingga Siwa terkecil yang terbuat dari bunga jepun dan daun kayu Arjuna. Berdasarkan teologi Siwa, Sang Hyang Siwa berstana di dalam kalpika dan Sang Hyang Surya dinyatakan sebagai murid dari Sang Hyang Siwa yang paling mahir dalam ilmu pengetahuan.

\section{Makna Teo-Filosofis Barong-Rangda}

Barong sebagai Banaspati Raja adalah wujud Kalarudra, yaitu Siwa yang tengah bertiwikrama. Tiwikrama adalah mengubah diri menjadi luar biasa hebat untuk mengatasi berbagai bentuk penghalang dan rintangan. Tampilan Barong mesolah (menari) yang menunjukkan wujud triwikrama Siwa adalah saat Barong menari sambil ngeretek (rahang gemertak) mempermainkan kedua rahangnya sehingga antara barisan gigi atas dan bawah saling beradu menimbulkan suara menakutkan. Demikian juga kaki-kakinya keteb-keteb (menjejak dengan keras-keras) pertiwi (bumi) hingga menyebabkan gempa bumi dan para asura lari ketakutan. Pada kakawin Smaradahana pupuh VIII: 7-10 melukiskan triwikrama Siwa sebagai berikut.

a. Dewa Siwa yang Agung bangkit dengan marah,

b. Seperti dengan sendirinya ia segera mengambil bentuk triwikrama

c. Dengan garang dan mengerikan ia menempatkan dirinya di tengah-tengah angkasa (bahkan) raksasa diantara raksasa setengah menatapnya dengan takut dan gemetaran

d. Ia mengembangkan dirinya dalam bentuk Rudra dengan kepala 5 yang tak terukur

e. rambut kusut yang menakutkan,berkilauan dan rapat

f. seperti mega -mega pada waktu kehancuran, berikal kemerah-merahan

g. dengan menakutkan (ia menjulurkan seribu lengannya ke segala arah)

h. Matanya seperti bulan-bulan dan matahari-matahari yang berderet dengan bentuk setengah lingkaran dan dalam seperti gua lubang hidungnya (lebar) dan dalam seperti gua

i. Mulutnya dengan taring-taring tajam seperti (pintu gerbang) kematian oleh gemertak giginya menjadi halilintar dan badai yang tiada putus-putusnya

j. Ia seperti gunung (dengan lengan-lengan) dan kaki-kaki pada kedua sisinya

k. Bulu-bulu badannya yang bergantungan dari tubuhnya bisa disamakan dengan senja hari

1. Pada tiap bidang tanah tempat ia meletakkan kakinya terjadi gempa (bumi) bergoncang seakan-akan robek oleh tindakan kakinya

Gautama dan Sariani (2009:527) menyebutkan Rangda memiliki arti: (1) janda; (2) peran dalam cerita Calonarang sebagai janda tukang sihir dari girah dengan mengenakan topeng yang menyeramkan, mata besar melotot, taring besar-besar, rambut putih terurai lidah panjang, serta kuku panjang. Sementara itu Mardiwarsito (1986:463) dalam kamus Jawa Kuno menyebutkan "randa” berarti janda. Hal ini dipertegas oleh Segara (2000:20) yang menyebutkan istilah Rangda adalah bahasa Bali alus untuk penyebutan janda dari kalangan Tri Wangsa di Bali (Brahmana, Ksatrya, Wesya), sedangkan janda dari kalangan Sudra Wangsa dikenal dengan sebutan balu/walu. Pada kalangan masyarakat umum di Bali istilah Rangda lebih dekat pada pengertian sosok tokoh berperingai jahat yang mempraktikkan ilmu hitam untuk menghancurkan masyarakat. Persepsi ini muncul karena masyarakat lebih akrab dengan pementasan seni drama Calonarang yang menempatkan Rangda sebagai tokoh antagonis di dalamnya. Rangda dalam cerita Calonarang ini adalah figur janda dari Raja Girah, sebuah wilayah kecil di Kerajaan Kediri, Jawa. Namun melihat kenyataan bahwa Rangda di Bali tidak semata-mata berfungsi sebagai peranti berkesenian, tetapi lebih penting fungsinya sebagai peranti keagamaan (arcanam/tapakan), maka perlu ditemukan pengertian yang lebih tepat menyangkut keberadaan Rangda tersebut. Untuk keperluan tersebut, selain mengacu pada Lontar Siwa Tattwa di atas, terdapat juga penyebutan Barong dan Rangda dalam Lontar Usadha Taru Pramana sebagaimana disebutkan bahwa ketika Sang Hyang Siwa mengalami sakit keras atau gering yang parah. Untuk itu Sang Hyang Siwa menyuruh Dewi Uma mencari obat ke madyapada. Dalam pencarian obat untuk Dewa Siwa, Dewi Uma bertanya pada setiap pohon dan rumput-rumputan (sarwa taru dan sarwa lata). Kesemua pohon dan rumput itu dapat menjawab dengan baik, karena masing-masing sudah ada penghuninya, selanjutnya menerangkan khasiatnya masing-masing mulai dari akar, kulit, sampai dengan daunnya. Tepatlah pada tengah hari (kali tepet) sampailah Bhatari Uma di Setra Gandamayu, pada sebuah pohon besar, yaitu: Taru Rangdu, di sana beliau mengadakan tanya jawab tentang manfaat khasiat pohon tersebut. Kebetulan pada waktu itu merupakan hari yang terlarang oleh Sang Kala Banaspati Raja, karena pada saat itu yang menghuni pohon tersebut sedang tidur nyenyak.

Mendengar suara ribut-ribut dan pada waktu yang salah (nyalah masa), maka Sang Banaspati Raja bangun dari tidurnya karena merasa wajib nadah atau memangsa orang yang ada di hadapanya seraya ia menyerang Bhatari Uma dengan sengitnya sehingga pertempuran pun tidak terelakkan. Dalam mempertahankan diri lalu Dewi Uma terpaksa merubah diri (Nyuti Rupa) kembali menjadi Dewi Durga yang amat menyeramkan, untuk menandingi kesaktian Sang Banaspati Raja. Adu kesaktian antara keduanya 
menyebabkan Sang Banaspati Raja mengalami kekalahan karena beliau berhadapan dengan penguasa maut. Oleh karena itu pantaslah Sang Banaspati Raja dikalahkan. Sang Banaspati Raja dalam pertempuran itu melarikan diri, karena mendapatkan pukulan yang dahsyat dari Dewi Durga. Melihat tuannya dikalahkan oleh Dewi Durga, maka rakyat Sang Banaspati Raja yang terdiri atas mahluk alus amatlah marah dan dengan serta-merta menyerang Dewi Durga bertubi-tubi. Akan tetapi setiap pasukan yang terdiri dari wong samar tersebut berhadapan dengan Sang Dewi Durga mengalami kekalahan hanya wibawa dan kengerian memandang wajah Bhatari Durga. Akhirnya Sang Banaspati Raja mengubah dirinya menjadi binatang yang sangat sakti dengan suara gemerincing dikakinya dan bertempur dengan Dewi Durga (Yudabakti, 2007:48-50).

Berdasarkan penegasan dalam Siwa Tattwa maupun Lontar Usadha Taru Premana, Rangda secara tegas disebutkan sebagai penjelmaan Dewi Uma/Dewi Durga di bumi. Bilamana sebelumnya wujud Barong dinyatakan sebagai penjelmaan Dewa Siwa, maka sangat tepat kalau Rangda adalah perwujudan Dewi Durga sebagai Saktinya (pasangan) Dewa Siwa. Dengan demikian, untuk menempatkan Rangda dalam khasanah budaya Hindu (Bali), maka penyebutan istilah janda untuk Rangda kurang mewakili makna yang disandangnya. Oleh sebab itu dalam tulisan ini istilah Rangda yang dimaksud akan mengacu pada Lontar Siwa Tattwa dan Lontar Usada Taru Premana, bahwa "Rangda adalah perwujudan Dewi Durga di bumi bergelar Hyang Bherawi dengan ciri-ciri wajah seram menakutkan, rambut terurai panjang, mata melotot, lidah menjulur panjang, dan kuku panjang." Definisi tersebut lebih dapat mewakili kehadiran Rangda dalam fungsinya sebagai peranti keagamaan maupun sebagai peranti kesenian.

Wujud Durga yang seram juga ditegaskan dalam Kidung Sudamala, sebagaimana terjemahannya (Santiko, 1992:185) sebagai berikut:

Sang Hyang Tunggal adalah dewa utama,

Tidak dapat dipungkiri bahwa Sri Huma (Uma) berlaku

Serong,

berani membagi sirih dan bedaknya,

karena itu ia dikutuk oleh Sang Hyang Guru//4//

Sang Hyang Guru adalah dewa yang berkuasa,

Berbadankan alam semesta,

Tahulah ia segala-galanya yang tidak diketahui oleh manusia,

Ia pun tidak terlihat karena memiliki sifat: tiada//5//

Adapun yang diceritakan sekarang, Sang Hyang

Tunggal (dan) Sang Hyang Visesa telah memberi

kepada Hyang Guru seluruh tingkah laku Sri Huma,

Sang Hyang Guru sakit hatinya//6//

Karena itu tahulah ia bahwa istrinya berdosa,

Karena pernah melayani Hyang Brahma, Guru

Sangatlah marah//7//

Dicaci makilah Batari Huma, katanya: Sudahlah

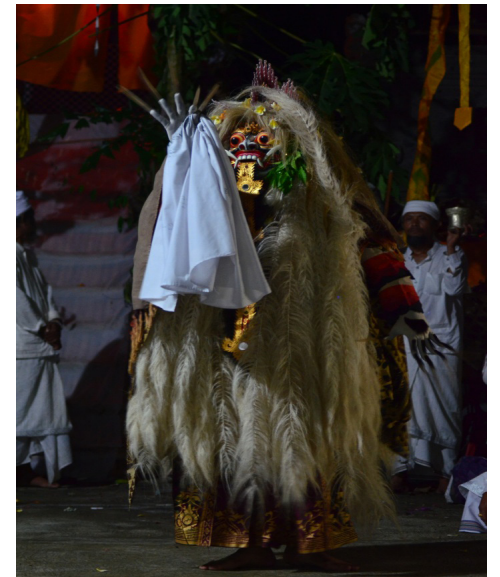

Gambar 3. Rangda Adalah Wujud dari Bhatari Durga Dalam Aspeknya Sedang Murka/Marah

(Sumber: Gases Bali,2016)

Jelas sekarang," diacungkanlah jari telunjuknya Segera (Huma) berubah menjadi Durga//8//

Itu adalah hasil perbuatannya sendiri (seperti)

Orang mandi membasahi dirinya. Terlaksanalah kutukannya:

Segeralah kamu menjadi Durga,

Namamu adalah Ra Nini//9//

Seperti kapur (tercampur) dengan kunyit,

Rambutnya lengket tak berantara, berwarna merah,

Gimbal, berlilit-lilit, tubuhnya tinggi besar//10//

Matanya seperti matahari kembar, mulut seperti gua terbuka.

Taring runcing, hidung lebar menganga seperti sumur

Lihatlah tubuhnya//11//

Badannya bertotol-totol. Menjerit berteriaklah ia minta diruwat, maka berkatalah Batara Guru:

"Tidak bersih dari dosa kamu sekarang."//12//

Gambaran Durga dalam Kidung Sudamala menyerupai bentuk Rangda di Bali, yaitu rambut kusut merah kusam, mata melotot lebar, taring tajam dan mulut lebar dan berkenaan dengan makna atribut Rangda. Hal ini semakin menegaskan bahwa wujud Rangda di Bali adalah bentuk yang mewakili Durga, dan bukan penggambaran seorang janda ataupun yang lain. Olehnya, berkenaan dengan pengertian Rangda sekiranya tepat merujuk pada teks-teks sastra tertentu sehingga dapat diketemukan landasan yang kuat tentang pengertian Rangda. Sebagaimana disebutkan dalam teks lontar Siwa Tattwa, Usadha Taru Premana, bahwa Rangda adalah manifes dari Dewi Durga, yakni sakti dari Dewa Siwa. Dengan demikian, penggambaran Rangda adalah berdasarkan atas cerita-cerita dalam lontar tersebut yang menggambarkan sosok Dewi Durga yang menyeramkan.

\section{SIMPULAN}

Berdasarkan atas uraian tersebut di atas, dapat disimpulkan bahwasanya keberadaan Barong-Rangda sangat 
penting dalam kehidupan sosio-religius masyarakat Bali, sebab dapat memunculkan taksu. Barong-Rangda sakral yang dapat memunculkan taksu tentunya bukan dibuat sembarangan, tetapi dibuat berdasarkan atas sumber sastra sebagaimana ada liturgi atau tahapan yang teliti, sehingga Barong-Rangda dapat metaksu. Kemudian, makan teo-filosfis Barong berhubungan dengan konsep pemurthian Sang Hyang Banaspati Raja dan Rangda adalah aspek Bhatari Uma yang sedang krura atau murka.

\section{DAFTAR RUJUKAN}

Agus, Bustanuddin, 2007. Agama dalam Kehidupan Manusia Pengantar Antropologi Agama. Jakarta: PT. Raja Grafindo Persada.

Bandana, I Gede Wayan Soken, 2009. Ritual Tolak Bala Masyarakat Bali. Denpasar: Pustaka Larasan.

Darma Putra, S.H., A.A. Ngr., 2002. Ajaran-Ajaran Sepiritual Pengendalian Diri. Denpasar: CV. Kayumas Agung.

Dibia, I Wayan. 2004. Pragina; Penari, Aktor dan Pelaku Seni Pertunjukan Bali. Malang: Sava Media.

Eliade, Mircea, 2002. Sakral dan Profan. Yogyakarta: Fajar Pustaka Baru.

Krishna, Anand, 2015. Bhagavad Gita Bagi Orang Modern. Jakarta: Kompas Gramedia.

Kutha Ratna, Nyoman, 2007. Estetika Sastra dan Budaya. Yogyakarta: Pustaka Pelajar.

Pendit, Nyoman S., 1991. Bhagavadgita. TT: Yayasan Dharma Sarathi.

Riana, Jro Mangku I Ketut, "Geguritan Sudamala dan Candi Sudamala dalam Perbandingan," dalam Poestaka No. 5 Tahun XIV, Februari 2003. Denpasar: Fakultas Sastra Universitas Udayana.

Santiko, Hariani, 1992. Bhatari Durga. Depok: Fakultas Sastra Universitas Indonesia.

Segara, S.Ag., Nyoman Yoga., 2000. Barong dan Rangda. Surabaya: Paramita.

Titib, I Made, 2000. Teologi \& Simbol dalam Agama Hin$d u$. Surabaya: Paramita.

Titib, I Made, 1996. Veda Sabda Suci Pedoman Praktis Kehidupan.Surabaya: Paramita.
Yudhiantara, Kadek, dan Chandika Sila Ulati Devi, 2003. Rahasya Pemujaan Sakti Durga Bhairawi Meditasi, Mantra dan Hakekat Devi Dasa Mahavidya. Surabaya: Paramita.

Tim Pengkajian Naskah Lontar Siwagama, 2002. Kajian Naskah Lontar Siwagama. Denpasar: Dinas Kebudayaan Propinsi Bali.

Tim Penterjemah, 1986. Usana Bali Usana Jawa Teks dan Terjemahan. Denpasar: Dinas Pendidikan dan Kebudayaan Propinsi daerah Tingkat I Bali. 